Historic, Archive Document

Do not assume content reflects current scientific knowledge, policies, or practices. 



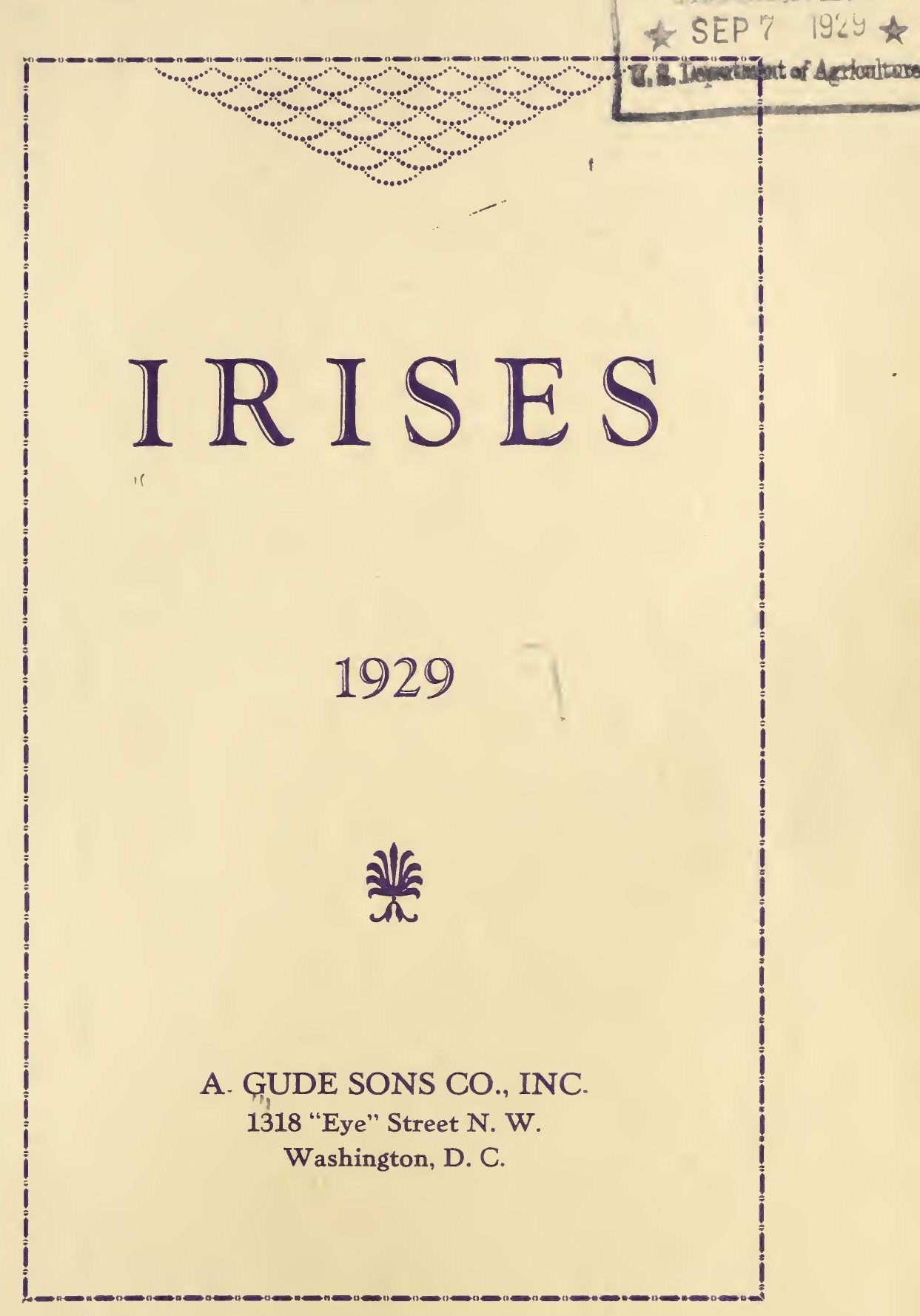


Our stock is known to be true to name. All orders will be booked and shipped in rotation, subject to stock being unsold and available on receipt of order.

Place your orders early to avoid disappointment, as our stock of some varieties is limited. Early planting, immediately after the blooming season, will insure the greatest possibility for bloom the following spring.

We guarantee all plants to be delivered in good order. If plants should arrive in an unsatisfactory condition, they should be returned immediately. We cannot guarantee our plants to become established under all growing conditions, but we do guarantee good, strong, healthy roots, which, with the proper planting and care, will produce the maximum of bloom. 


\section{THE GARDEN}

GOOD example is infectious and whoever starts a garden invites emulation. Man must have some hobby outside of the common round, the daily task, otherwise his life is not well balanced.

Long ago gardening was acclaimed the greatest of human pleasures, the greatest refreshment to the spirit of man. And those who plant a garden, best know this wisdom.

To get closely in touch with nature, to watch the procession of seasons, to note how change, wondrous change, proceeds and how natural laws govern the bursting of buds and unfolding of the flowers is wholesome and leaves no time for ennui.

To plant some flower and watch it develop to perfection is a fascinating and fruitful pastime. It is creative and rich in object lessons to youth and maturity.

As nations come to culture, love of the beautiful prevails. There is nothing more beautiful than a flower and no flower so precious as that raised by our own efforts in our own garden, be it ever so small.-E. H. Wilson. 


\section{INTRODUGTION}

\section{HISTORICAL}

This catalog of Irises is presented by the firm of A. Gude Sons Co., Inc., whose connection with Horticulture and Floriculture began in Washington, D. C., in the year 1888.

In 1927 we acquired an old Maryland farm comprising 371 acres. It adjoins the thriving and progressive town of Rockville, which is some 15 miles North and a little West of the Nation's Capitol.

Here we have developed a modern nursery devoted to a general nursery business, which includes our specialty: the growing of roses for the wholesale cut-flower trade.

Recognizing the popular demand for that most versatile and accommodating of all garden perennials, the Iris, we established a large Iris garden laid out in crescentric beds with broad walks radiating from the center. Here are grouped nearly all of the better varieties of the Tall Bearded Irises arranged with careful attention to color harmony under the direction of the eminent Iris authority, Mr. B. Y. Morrison.

IRIS ANATOMY

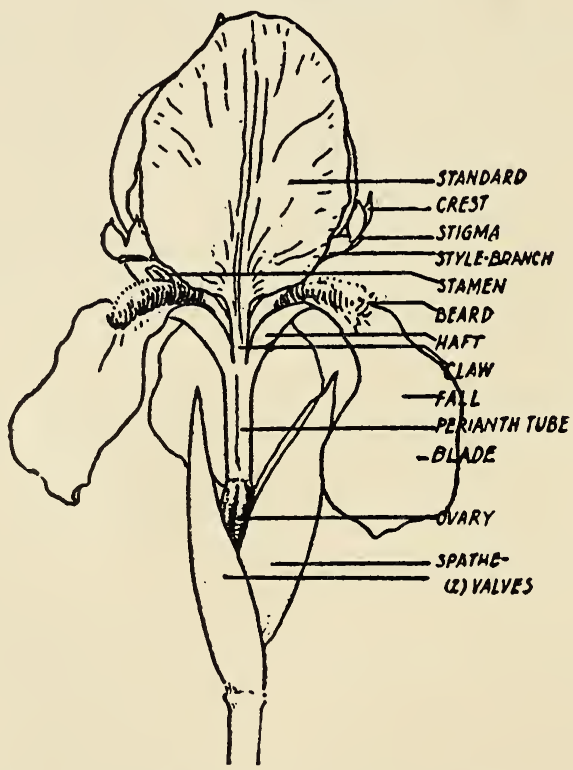

To assist you in placing the colors mentioned in the following pages we have included a skeleton sketch of the Iris flower, with explanatory legends. STANDARDS refer to the three upper petals and FALLS 
refer to the three lower petals of the Iris. They are abbreviated herein by the letters $S$ and $F$ respectively. The name of the originator, if known, and the year of introduction appear in parenthesis after the name of each variety.

\section{PLANTING AND CULTIVATING}

The first and only real obstacle to overcome is procurement. To meet this we have listed herein a choice array of the better Irises at prices which are in keeping with their availability to us, the rapidity with which they multiply and the low overhead of our organization.

The Iris will grow almost anywhere, providing two important requirements are fulfilled-"Heads in the sun and dry feet." Therefore select for your Iris planting a sunny location where there is good drainage. They will not prosper in low, damp, shady spots. Partial sun is permissible. In fact some varieties, like MOTHER-OF-PEARL, are at their best when grown protected from the blazing afternoon sun.

They are useful if not indispensable subjects, for bordering open wood-land paths and drives, to cover barren spots on hillsides, and are excellent for banks and terraces, to prevent erosion. They have real commercial value in this respect, for on the steep declivities of the Moselle and Rhine rivers, millions of these plants hold in the grasp of their matted roots the soil of vast vineyards.

\section{AVOID DEEP PLANTING}

Cut off the tops to within four to six inches of the fleshy root (rhizome), cut back the long fibrous roots, scoop out a shallow hole, cover with earth and "step on it."

Any month will do providing the ground can be worked. A light covering should be laid over them if the planting is done after August 1st, but this may be omitted if the work is done earlier in the season, as the roots will have "taken hold" and no heaving of the rhizomes may be feared the following winter. June and July are the most favorable months for transplanting. If you are in doubt, protect them by a light covering in the early Winter of their first year, using any available fibrous material, but this should be removed before growth begins in the Spring.

\section{FERTILIZATION}

While Irises are accommodating as to soil and location, they make an appreciative response to cultivation and fertilization. Magnificent specimens may be expected every season, year after year, if the plants and clumps are carefully weeded, grass pulled up, the surface of the 
soil lightly stirred and bone meal dug in around their roots in the Fall.

Soil reaction is not important, an alkaline or mildly acid soil will serve their purposes admirably.

\section{DISEASE}

Iris Rot is about the only disease to be feared and it is the result of bad environment. Do not waste your time and money by attempting to cure it with antiseptics, but simply dig up the affected roots, cut away the evil smelling and decomposed portion and plant the healthy remnant rhizome in a more favorable spot. It is also good practice in the late Summer to pull away all blades which have become discolored. Large clumps should be thinned out or divided as they become crowded. This will occur every four or five years, depending upon the rapidity with which the particular clump multiplies. These simple directions will result in your marking the date of your first Iris bloom as surely as you did the advent of the Easter Rabbit, more or less years before.

\section{GROWING NEW VARIETIES}

The development of new varieties from seeds has been left to the specialist but it may well be practiced by anyone. They will bloom the second year from seeds planted in the early Fall and if a few simple rules are followed with reference to utilizing sturdy and exceptional stock for pollen and seed parents, the results are bound to be worth the trifling effort, not to mention the possibility of a magnificent new variety for the pleasure of succeeding generations.

To leave this vast field of endeavor in Iris research to the so-called or self-styled Iris specialist, enthusiast or hybridizer is on the assumption that they know what they are about. The fact is, they do not know. Inheritance is not fore-ordained and the "science of genetics has yet to produce a superior pod of beans or a flock of hens" according to the eminent geneticist, Raymond Pearl.

From this you may reason correctly that the efforts of the amateur are to be encouraged rather than despised. Bear in mind, however, that a worth-while subject may develop as a result of your efforts in the course of a life time and, it may not, but you will get varieties, all different, some of which will be equal or superior to many named and catalogued Irises now on the market. It is a fascinating pastime and is not yet prohibited by law. 


\section{Irises}

\section{LIST OF VARIETIES}

AMAS (Foster 1885) S. blue. F. violet-purple. Early flowering species from Asia Minor. The flowers are large and are inclined to flop somewhat in hot sun.

3 for $50 \mathrm{c}$

AFTERGLOW (Sturtevant 1917) 3 feet. Soft lavender-gray shading to buff. Well branched and vigorous grower. Attractive and useful

3 for $\$ 1.00$

ALBERT VICTOR ( $31 / 2$ feet) Handsome deep toned Pallida, Multiplying rapidly, having a long blooming period and is valuable for large clumps in the corners of the garden or landscape purposes 3 for $50 \mathrm{c}$

ALCAZAR (Vilmorin 1910) S. lavender-violet. F. velvety purple. Tall, sturdy grower. A sombre beauty from France------3 for 50c

AMBASSADEUR (Vilm. 1920) $3 \mathrm{r} / 2$ feet. S. dull coppery violet. F. Deep reddish-purple, flaring outward. Conspicuous orange beard. Competition increases its value. It possesses every virtue of a superior Iris 3 for $\$ 1.00$

AMBIGU (Vilm.) S. smoky red. F. reddish-purple. Multiplies slowly. Much admired 3 for $50 c$

ARCHEVEQUE (Vilm.) $1 \frac{1}{2} 2$ feet. S. deep violet. F. purple-violet. Small flowered variety but exceptionally rich_-_-_-_-_-_-3 for 50c

ASIA (Yeld 1916) 4I/2 feet. S. silvery lavender. F. pale reddish-purple. Bright golden beard. Stately, majestic and fragrant. Flowers well formed and wonderfully colored. Multiplies slowly but you will not mind that each, $\$ 1.50$

APHRODITE (Dykes 1922) 4 feet. Bright pink-violet self. Grows vigorously and blooms longer than any other. Parents unknown. It came unheralded and unexpectedly in a bed of Pallida seedlings. Has a great future. each, $\$ 5.00$

ARLINGTON (Simpson 1923) 3 feet. S. rosy lavender. F. bright velvety reddish-violet. General garden effect light red. A large brilliant flower from a garden in Virginia_-_-_-_-_-_-_-_-_-_--3 for $\$ 1.00$

AUTUMN KING (Sass) 2 feet. A large, well formed blue bicolor which blooms in May and again in October with unfailing regularity each, $\$ 1.00$

AURORA (Yeed 1909) 4 feet. Light pink of good habits and like many of the delicately colored, appreciates some shade 3 for $\$ 1.00$ 
BARTON HARRINGTON (Fryer) 2 feet. S. clear golden yellow. F. brown with a reddish tone. Above the average. Not as good as Solana or Iris King which it resembles, but worth having

3 for $50 c$

CARDINAL (Bliss 1919) 3 feet. S. bronzy lavender. F. raisin purple. As beautiful as Dominion but a much better Iris for the garden.

each, $\$ 10.00$

BARONET (Sturt) $3 \mathrm{x} / 2$ feet. S. chicory blue. F. blue-violet. Garden effect blue at close range. Good but not indispensable_-3 for $\$ 1.00$

BALLERINE (Vilm.) $2 \frac{1}{2}$ to 3 feet. S. blue-violet. F. wisteria-violet. Flower has a crisp, crinkled appearance and possesses a silvery sheen. Lemon beard. Falls almost circular. An incomparable Iris in the class.--_-_-_-_-_-_each, $\$ 1.00$

BRANDYWINE (Farr 1920) Chicory blue self of great merit. Slow reproducer --_-_-_- $\$ 1.00$

BEAU IDEALS (Sass) White plicata with an almost solid border of petunia violet on both standards and falls 3 for $\$ 1.00$

B. Y. MORRISON (Sturt.) Standards lavender-violet. F. raisin purple with pale wide border. Striking and unusual. 3 for $\$ 1.00$

BLACK PRINCE (Perry 1900) F. black-purple with bright orange beard. Exceedingly rich effect. Multiplies very slowly and requires leaf mold and partial shade. each, $\$ 1.00$

CATERINA (Foster-Wall 1909) 4 feet. Massive lavender flowers on sturdy flexuous stems. Similar to Pallida Dalmatica but larger and more veined. Sweetly fragrant. Requires good drainage.

3 for $\$ 1.00$

COL. CANDELOT (Mil. 1907) S. smoky copper. F. crimson held horizontally. Unique and in a class by itself for red effect.---3 for 50c

CONQUISTADOR (Mohr) 5 feet. A violet-mauve giant from California. Not recommended unless you are willing to give it the special care which it demands_-_-_-_-_-_-_-_-_-_each, $\$ 1.50$

CRETONNE (Bliss) 3 feet medium size. Red-purple tones. Orange

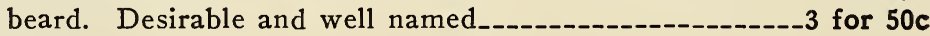

CRUSADER (Foster 1913) $3 \mathrm{x} / 2$ feet. Well branched, clear blue bi-color with orange beard. Large flowers. Garden effect blue. Has stiff competition but maintains its place among the blues_----3 for $\$ 1.00$

CRIMSON KING (2⿺辶/2 feet) Deep, rich, dark red-purple, close to Kochii. In fact so close that one should not have both. Increases rapidly and is a very good Iris.-_-_-_- $50 \mathrm{c}$ 
CORRIDA (Mill. 1914) A fine light blue with medium size flowers borne over a long season.

3 for $50 \mathrm{c}$

CLUNY (Vilm. 1920) S. pale lilac blue. F. deeper color. Exquisite shade of blue and floriferous 3 for $\$ 1.00$

CAPRICE (2 feet) S. reddish-purple. F. deeper. A very good red self 3 for $50 c$

CAMELOT (Bliss 1918) 4 feet. White margined with pale violet blue. Free flowering 3 for $50 \mathrm{c}$

DEJAZET (Vilm. 1914) S. rose orange. F. reddish-violet. Medium size flowers. Takes its own time in multiplying---_------3 for 50c

DALILA (Dennis 1914) S. white slightly tinted lilac. F. rich red-purple. Yellow beard. Multiplies slowly. Should be in every collection 3 for $50 \mathrm{c}$

DUKE OF BEDFORD (Bliss) Seedling of Dominion. S. deep violet. F. much deeper tone. General effect, deep violet with a shade of red throughout (Bonnewitz) each, $\$ 5.00$

DAPHNE (Bliss 1920) A much improved Rhein Nixe and close to Mildred Presby. Increases slowly. S. white. F. blue_-each, $\$ 1.00$

DREAM (Sturt. 1918) A light pink Pallida. The most popular pink of American origin 3 for $\$ 1.00$

DOMINION (Bliss 1917) A magnificent blue-violet indigo-purple combination. In fact so good that someone purloined all of our original stock some years ago. This variety will be scarce for years. Produces seedlings which are superior to the parent. Valuable for breeding purposes

each, $\$ 5.00$

DR. BERNICE (2 feet) S. coppery bronze. Reproduces rapidly. Exceptionally vigorous and blooms for a long period. Large stock. Attractive price 3 for $50 \mathrm{c}$

DIADEM (Bliss) S. lilac rose. F. mauve. Bright orange beard. Has

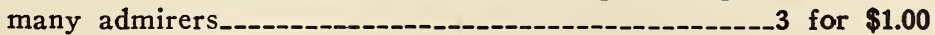

EGLAMOUR (Hort. 1921) An immense purple bi-color. Increases slowly. The largest Iris we have each, $\$ 1.00$

ECKESACHS (G. \& K.) Early blooming variety with lavender-violet standards and deep violet falls. Very charming. Stock limited.

3 for $\$ 1.00$

E. H. JENKINS (Bliss 1919) A superior blue-purple bi-color bloooming with exceptional freedom. Reproduces slowly and is therefore scarce. You must have this one 3 for $\$ 2.00$ 
A. Gude Sons Co., Inc.

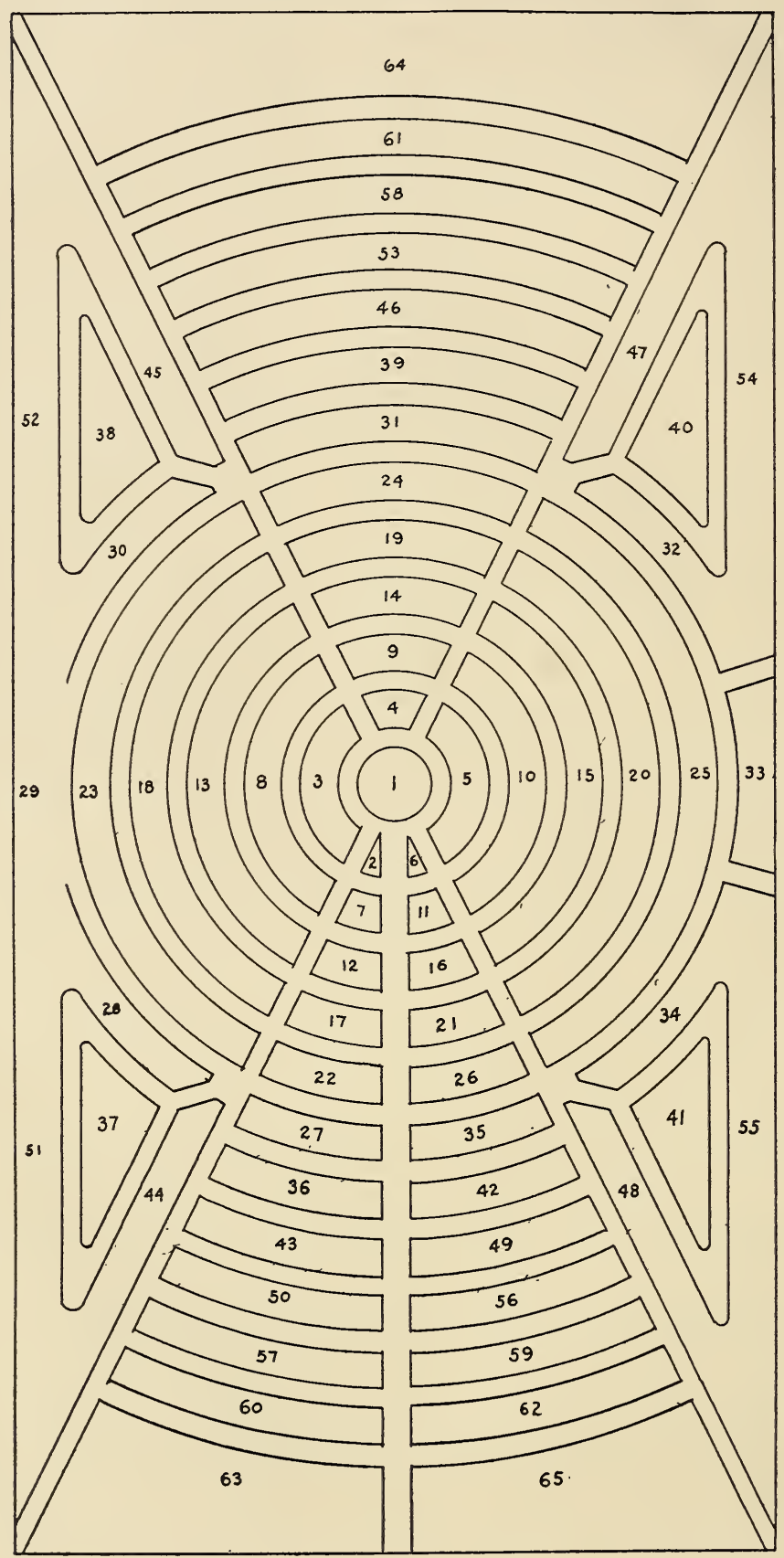




\section{KEY TO OUR IRIS GARDEN}

1. Solana

2. Opera

3. Rhein Traub, Asia and Julia Marlowe

4. Cretonne

5. Seminole

6. Sweet Lavender

7. La Neige

8. Iris King

9. Miranda

10. Shekinah

11. Mt. Penn

12. Harriet Presby

13. Juniata

14. E. H. Jenkins

15. Alcazar

16. Halo

17. Crusader, Black Prince

18. Rhein Nixie

19. Isoline

20. Lorelei

21. Lohengrin

22. Parc de Neuilly

23. Pallida Dalmatica

24. Monsignor

25. V i o le ci a Grandiflora, Nine Wells, Quaker Lady

26. Mme. Gaudichau, Saul

27. Kathryn Fryer

28. Mother of Pearl

29. Afterglow, Tristram, Dejacet

30. Virginia Moore

31. Ambassadeur, Igouf, Romeo, Mrs. W. E. Fryer, Caterina Gracchus, Julia Marlowe, Morning Splendor, Seedlings

32. Lent. A. Williamson

33. Mme. Chereau

34. Fairy

35. J a c que sia n a, Tropic Seas, Aurora

36. Col. Candelot

37. Queen Victoria Louise
38. Eldorado

39. Prosper Laugier

40. Perfection

41. Queen Caterina, Mme. Cheri, Cluny, Ma Mie

42. Arlington, Morning Splendor, Carthusian, Jubilee

43. Mauvine

44. Albert Victor

45. Perfection

46. Seedlings, Nibelungen, Pauline

47. Mme. Chereau

48. Juniata

49. Albert Victor

50. White Knight

51. Shrubs and Perennials

52. Shrubs and Perennials

53. Her Majesty

54. Shrubs and Perennials

55. Shrubs and Perennials

56. Caprice, Edouard Michel, Lady Foster

57. Ballerine, Sass No. 70, Autumn King

58. Mildred Presby, Lord Lambourne, Pioneer, Duke of Bedford, Eglamour, Mme. Durand, Dominion, Queen Mary, Rosealba, Sass No. 25, Mme. Chobaut, Parisiana, Grevin, Paulina, Dalila, Diadem, Corrida, Queen of May

59. Baronet, Blanche Peon, Camelot, Conquistador, Sunset

60. Georgia, Prospero, V a 11 er y Mayet

61. Roseway, Archeveque, Lepinaux, Sass No. 54, San Gabriel, Rodney, Thorbeck, Cashmierana, Sindkhat

62. Anna Farr, Drake

63. Shrubs and Perennials

64. Shrubs and Perennials

65. Shrubs and Perennials

\section{SEE OUR IRIS GARDEN IN BLOOM}

(This garden covers nearly two acres, and when in full bloom, presents a spectacle well worth reviewing)

You are cordially invited to visit our Nurseries in Rockville, Md., during the Iris blooming season, which will begin this year about the second week in May and continue throughout the month. 
ELDORADO (Vilm.) Distinct and pleasing bronze heliotrope and violetpurple with a brilliant yellow beard. General garden effect deep golden yellow. Attractively priced-_-_-_-_-_-------6 for 50c

EDOUARD MICHEL (Verd. 1904) Deep red-violet. Frilled standards. Wide falls. Distinctive. Reproduces slowly. Garden effect pink.

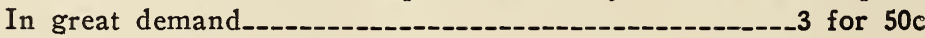

FRANKLIN BEYNON (Per. 1923) Rosy mauve self. Blooms over a long period. A desirable Iris in every particular--_-_-_-_each, 50c

FAIRY (21/2 feet) Free blooming white of medium size with blue tone styles. Has the fragrance of orange blossoms. A dainty, graceful, bewitching, well named flower---_-----------_3 for 50c

GREVIN (Vilm.) $2 \frac{1}{2}$ feet. Large flowers. S. violet and yellow. F. deep violet with yellow veining. Increases slowly-_-_-_3 for 50c

GAVIOTA (Mohr 1923) White edged yellow. Medium height and size. A distinctive Iris recently introduced from the golden west.

each, $\$ 1.00$

GEORGIA (Farr 1920) $3 \mathrm{r} / 2$ feet. S. and F. soft shade of rose. Bright orange beard. A beautiful, delicately colored variety originating in the gardens of the late B. H. Farr-_-_-_-_-_-_-_-_3 for 50c

GRACCHUS (early flowering) S. light yellow. F. brownish-crimson with purple markings

6 for $50 \mathrm{c}$

HARRIET PRESBY (Presby 1922) $3 \frac{1}{2} 2$ feet. Pink self. Large flower somewhat like Aphrodite. Desirable 3 for $50 \mathrm{c}$

HERMIONE (New) Late flowering. Purple self. Is far from a perfect Iris as it has been called._-_-_-_-_-_-_-_-_each, $\$ 1.00$

HER MAJESTY (Perry) $2 \frac{1}{2}$ feet. S. pale pink. F. deeper shade. An old standby. Not rated among the finest but is easily a favorite with those who like grace and beauty along conservatory lines.

6 for $50 \mathrm{c}$

HALO (Yeld) A vigorous free blooming Iris with delicate soft tones of lavender-blue and violet

3 for $\$ 1.00$

ISOLINE (Vilm.) $21 / 2$ feet. S. lilac pink. $F$ old rose. Has a golden throat and a yellow beard. Excepting for the drooping falls which hug the stem, this is one of the most beautiful. A general favorite 3 for $50 \mathrm{c}$

IRIS KING (G. \& K.) 2 feet. S. old gold. F. rich velvety crimson maroon edged with gold. Some have claimed introduction just as good or better, but we refuse to be led astray. You will like it and will be perennially thankful for having acquired this beautiful Iris. 3 for $50 \mathrm{c}$ 
IGOUF (Mil.) A lavender-blue Iris which has a cream and tan edge on its standards and canary markings at the throat of the falls. Is of medium size. 3 for $\$ 1.00$

JACQUESIANA (Lemoine 1840) $2 \mathrm{~T} / 2$ feet. S. coppery crimson. F. maroon. Originated nearly a century ago but continues to hold

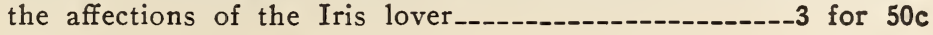

JUNIATA (Farr) Exceptionally sturdy variety. Three feet tall. Clear blue-violet self. One of our favorites._-_-_-_-_-_-_-_-_- 3 for $50 \mathrm{c}$

JULIA MARLOWE (Shull) $3 \mathrm{~T} / 2$ feet. S. Chinese violet. F. raisin purple. Flower measures three inches wide by five and a half inches high. Vigorous grower, producing abundant blooms on well branched stems. Form of flower displeases some, but we hold it in high favor. A recent introduction.--_----_-_-_each, $\$ 2.50$

JUBILEE (Sass) Buff, heavily spotted dark copper. Medium size, free blooming Iris. Admired by some but we could live without it.

3 for $\$ 1.00$

JUNONIA (Species) $3 \mathrm{I} / 2$ feet. S. soft blue. F. violet-blue-purple. Large flower of good form and substance---_-----------3 for 50c

KOCHII (2 feet) Early flowering, deep purple self. Well known and so common it has been dropped from many lists, but, to our way of thinking, it belongs in every garden in America 6 for $50 c$

KATHRYN FRYER (Fryer 1917) S. straw yellow. F. velvety maroon with white and yellow markings. Orange beard. A late flowering, fragrant variety 3 for $50 c$

LADY FOSTER (Foster) $3 \frac{1}{2}$ feet. S. pale blue. F. light blue-violet, veined old gold at the throat. Massive flower gracefully held on long stem. It has never been unfavorably criticised to our knowledge. Requires good drainage-_-_-_-_-_-_-_---_-_3 for $\$ 1.00$

LEVERRIER (Dennis 1917) 31/2 feet. Enormous flower of Chinese and pansy violet. Magnificent when well grown which is not often. each, $\$ 1.00$

LE NEIGE (Verd. 1912) A glistening creamy white with a yellow beard. Establishes slowly but reproduces fairly rapidly and is held in high esteem.--_-_-_-

LENT A. WILLIAMSON (Wilsm. 1918) S. lavender-violet. F. pansy violet to cotinga purple. All that an Iris should be. Known to the initiated as Lent A. or L. A. W. The Iris which put Bluffton, Indiana, on the map 3 for $\$ 1.00$ 
LOHENGRIN (G. \& K. 1910) A blending in shades of cattelya mauve. Robust and floriferous. Almost invariably criticised by Iris fans but owned by all of them. A superior Iris for landscape purposes 6 for $50 c$

LORELEI (G. \& K. 1909) 2 feet. Standards light yellow. F. ultramarine blue. Garden effect yellow 6 for $50 \mathrm{c}$

LORD LAMBOURNE (Perry) $3 \mathrm{~T} / 2$ feet. S. rose faun. F. rich crimson. Bright yellow beard. Said to be a magnificent variety_-each, $\$ 3.00$

LEPINOUX (Mil. 1923) S. aniline blue. F. deep purple. Large flower on the tallest of stems. Must be well drained 3 for $\$ 1.00$

MME. CHOBAUT (Dennis) 3 feet. S. white shot through with citron yellow shading to wine red. F. white margined lilac. Fragrant, delicately colored and much admired variety 3 for $50 \mathrm{c}$

MORNING SPLENDOR (Shull 1922) Large beautifully formed flowers of a rich red-purple color. Attractive in the "morning sun," but not after the evening rain. Somewhat temperamental as to location. Rated above 90 . Silver medal A. I. S. 1926_----_each, $\$ 2.50$

MOTHER OF PEARL (Sturt.) 4 feet. A soft lavender, widely advertised. Develops its full beauty in the semi-shade. Very fragrant, ladies' favorite 3 for $\$ 1.00$

MADAME GAUDICHAU (Mil.) 3r/2 feet. S. Bradley's violet. F. dark purple. Among the first ten Irises in all the world. Some day we hope to see an acre of it in bloom 3 for $\$ 2.00$

MRS. TINLEY (Bliss 1919) An excellent violet-blue bi-color with a conspicuous orange tipped beard 3 for $\$ 1.00$

MA MIE (Cayeux 1906) $2 \mathrm{~T} / 2$ feet. Early blooming white frilled with blue. You will probably get as good an Iris in your first crop of seedlings -6 for $50 \mathrm{c}$

MAGNIFICA (Vilm.) 4 feet. S. violet-blue. F. reddish-violet reticulated brown. Fragrant. Splendid flower of brilliant contrast. A French nobleman with a Roman name. It is distinguished, glorious and sublime. each, $50 \mathrm{c}$

MT. PENN (Farr) 21/2 feet. S. rose, shaded violet. F. crimson suffused with violet. Prominent deep yellow beard. Requires no label regardless of the number of Irises in your garden 3 for $50 \mathrm{c}$

MILDRED PRESBY (Farr 1923) 21/2 feet. S. palest yellow, nearly white. F. deep rich velvety violet. This was a favorite of Mr. Farr's, than whom there was no better judge. each, $\$ 2.00$ 
MIRANDA (Hort. 1919) 3 $3 / 2$ feet. A clear deep violet-blue. You will remember this one after having seen it in our garden_-3 for $\$ 1.00$

MEDRANO (Vilm. 1920) S. reddish copper. F slightly darker crimson purple. Flecked with buff and lavender 3 for $\$ 1.00$

MADY CARRIERE (Mil.) 3 feet. S. pale plumbago-blue. F. ageratumblue shading to rich yellow at the base. Possibly superior to Afterglow which it resembles

3 for $50 \mathrm{c}$

MLLE. BLANCHE PION (2⿺辶/2 feet) S. bronzy-yellow. F. lavenderblue. Margin silver. Has its admirers, although not many. We rate it an uninteresting Iris

3 for $\$ 1.00$

MLLE. DURRAND (Dennis 1912) S. dome shaped, old gold. F. old gold flushed with lilac. Requires protected location, good drainage and special care, but is worth it

$\$ 3.00$

MLLE. CHERI (Sturt. 1918) Ageratum-violet, flushed pink with a yellow under tone. An exquisite Iris, tall and vigorous_-each, 50c

MONSIGNOR (Vilm. 1907) S. pale violet. F. same shade but heavily veined with deep purple. A good Iris at a low price-_-_--6 for 50c

MRS. NEUBRONNER (2 feet) Rather small flowers of a rich, deep yellow

6 for $50 \mathrm{c}$

MRS. WALTER BREWSTER (Vilm. 1921) 3 feet. S. lavender-blue. F. aniline blue. One of the outstanding blue bi-colors_-3 for $\$ 1.00$

MIDWEST (Sass) $21 / 2$ feet. S. and F. light lavender, stippled brown. A curious and appealing flower. Makes a wonderful display under artificial light, which is something most Irises will not do.

3 for $\$ 1.00$

MRS. W. E. FRYER (Fryer) $21 / 2$ feet. S. pale mauve. F. dark purple with a lighter margin. A fairly good Iris 6 for $50 c$

NIEBELUNGEN (G. \& K.) S. faun-yellow. F. violet-purple on bronze. A flower of subdued tones -6 for $50 c$

NINE WELLS (Foster) S. light violet. F. deep purple-violet with a white patch at the throat. A late flowering subject, and fairly good, blooming on four-foot stems.

3 for $\$ 1.00$

OPERA (Vilm. 1916) S. pansy violet. F. violet-purple. General garden effect red. Useful because of its color, but it is difficult to establish and multiplies slowly3 for $\$ 1.00$

OCHRACEA-COERULEA (Syn. sunset) (Dennis 1919) A marvelous blending of buff, blue and gold. Has no faults, is universally admired and we give it our unqualified endorement_---_each, $\$ 1.00$ 
ODAROLOC (Andrews) Fine, tall Pallida with pink tones. Spell this word backwards and it would be well named each, $\$ 5.00$

PALLIDA-DALMATICA ( $3 \mathrm{x} / 2$ feet or better) S. and F. pale blue. The highest rating Iris and will eventually be planted by the millions. The origin of this variety is lost in antiquity. Seedlings inferior to the true variety have been distributed under the name. Some catalogues are listing a special form as Princess Beatrice and, for a good reason, a fancy price 3 for $50 \mathrm{c}$

PARC DE NEUILLY (Verd. 1910) 21/2 feet. A deep plum purple self. Flowers usually followed by a big flock of seed pods. Transmits its dusky tones to others, especially the Pallidas when crossed with them. Named for a park just outside of Paris where a R. C. Hospital was located during the World War------3 for 50c

PROSPER LAUGIER (Verd. 1914) S. sorghum brown. F. bordeaux to Indian purple 6 for $50 \mathrm{c}$

PARISIANA (Vilm. 1911) $2 \mathrm{r} / 2$ feet. S. white with blotches and dots of lilac-purple. F. white, frilled lilac. This one will also be dupli-

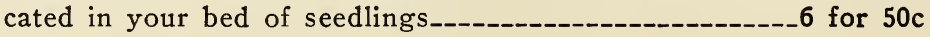

PROSPERO (Yeld 1920) A large, blended violet bi-color with yellow tones at the base of the standards and a brilliant orange beard. Requires staking to support the big crop of flowers on exceedingly long stems

3 for $\$ 1.00$

PAULINE (Farr 1913) 3 feet. S. and F. pansy violet. General garden effect bright pink. Good in all respects 3 for $50 c$

PIONEER (Bliss) Brilliant purple which the originator claims as a "pioneer in a new color for garden Irises." Comments from all sources are favorable. Stock limited. each, $\$ 10.00$

PERFECTION (Barr 1880) 21/2 feet. S. light blue. F. violet-black. Orange beard. An excellent low-priced variety 6 for $50 \mathrm{c}$

PRINCESS VICTORIA LOUISE (G. \& K. 1910) S. sulphur yellow. F. rich plum, border cream. This Iris should be planted in large clumps where a light yellow garden effect is wanted 6 for $50 \mathrm{c}$

QUEEN CATERINA (Sturt. 1917) 31/2 feet. Lavender-violet self of fine form and substance. Held in high regard by all lovers of Iris 3 for $\$ 1.00$

QUAKER LADY (Farr 1909) 21/2 feet. S. smoky lavender shaded yellow. F. ageratum-blue and old gold. In demand by landscape architects. Appeals strongly to feminine tastes. 3 for $50 c$

QUEEN OF MAY (Salter 1859) 21/2 feet. Soft rosy violet, almost pink. Common but in great demand 6 for $50 c$ 
ROSEWAY (Bliss 1919) 3 feet. Fine Iris for landscape purposes as the rose-lilac color is apparent at a distance._-_-_-_-_-_-_-_3 for $50 \mathrm{c}$

ROSEALBA (Bliss) Deep rose colored flowers 3 for $50 \mathrm{c}$

RAFFET (Vilm. 1920) A uniform dark blue with falls striped white at the base. Of no great value 3 for $50 \mathrm{c}$

RHEIN NIXE (G. \& K. 1910) $21 / 2$ feet. S. white. F. violet-purple. General garden effect white. Will some day be replaced by Mildred Presby but not until money is easy to acquire or the price of the latter falls to the same level_-_-_-_-_-_-_-_6 for 50c

RHEINTRAUBE (G. \& K. 1917) 3 feet. S. clear light blue. F. dark purple. Form of flower is attractive. The falls are almost horizontal. Exceptionally floriferous. Is easily a favorite with all of our visitors and rated by us in the first twenty-five of the world's fine Irises each, $\$ 1.00$

ROMEO (Mil. 1912) S. citron yellow. F. purple, lilac at center. You

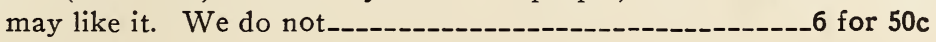

RODNEY (Bliss 1919) 3r $\frac{1}{2}$ feet. A fine dauphin's violet Pallida_3 for 50c

SASS NO 70 (Sass) The best dark red-purple self in our collection. S. dome shaped. F. approach horizontal. Original stock acquired five years ago and it holds a secure place in our affection_each, 50c

SWEET LAVENDER (Bliss 1919) S. Pale lavender-blue. F. roselavender. The form is exquisite and it is one of the most popular Irises in the garden. General effect rosy mauve

3 for $\$ 1.00$

SINDJKA (Sturt. 1918) Blend of dull lavender and olive buff and of mauve to manganese violet, which is an elaborate official de-

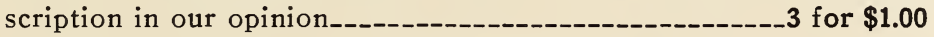

SAN GABRIEL (Dean) 4 feet. Colossal lavender-mauve. Requires staking and good drainage. A "Sun Kist" product accustomed to dry, sandy locations

3 for $\$ 1.00$

SEMINOLE (Farr 1920) A beautiful red toned bi-color. S. amparo purple. F. raisin purple. We like it immensely and so did $\mathrm{Mr}$. Farr who considered it one of his finest_-_-_-_-_-_-_--_3 for $\$ 1.00$

SHEKINAH (Sturt. 1918) 3-31/2 feet. As far as our information goes this is the only good, low-priced yellow of Pallida habit_3 for $\$ 1.00$

SOLANA (Shull) S. chrome yellow. F. bordeaux. General effect yellow. A very fine subject and one not found in the average catalogue. It occupies the key position in our planting, viz., the

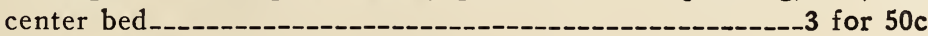

TRISTRAM (Bliss) S. Creamy white. F. deep rich red-purple, almost black. Striking subject but increases slowly 3 for $50 \mathrm{c}$ 
TROJANA (Species) S. Lavender. F. Red-purple. According to J. C. Nicholls this is not to be confused with Junonia, for it is a distinct species 3 for $50 c$

THORBECKE ( $2 \frac{1}{2}$ feet) S. White. F. prune purple. This one has been overlooked. Crowded out of the catalog by a lot of inferior Irises. To see it is th like it-_-_-_-_-_-_-_---_----3 for 50c

TROPIC SEAS (Shull) Not unlike and fully as good as Prospero. Vigorous grower and reproducer. Requires no staking and is first class in all respects each, $\$ 1.00$

TAFFETA (Cleveland) S. Heliotrope gray flushed olive buff. F. dull lavender of Pallida type. The ladies "just love it"-_-_-_-_3 for 50c

VALENCIA (Mohr 1926) Remarkable and unique coloring. Almost identical with the VALENCIA ORANGE. An outstanding variety

$\$ 2.50$

VIRGINIA MOORE (Shull) Medium height and flower. Lemon chrome self. Rapid reproducer and a very late and long bloomer_6 for 50c

VALERY MAYET (Dennis) Approaches red in general garden effect. Very good Iris. We have cut off a part of the long French name which is the only item about it we did not like

3 for $\$ 1.00$

VIOLACEA GRANDIFLORA (2 feet) S. and F. rich blue with a violet shade to the falls. Old, very old, but do not permit that fact to keep you from spending your money wisely -3 for $50 \mathrm{c}$

WHITE KNIGHT (Saunders) 2 feet. White with faint traces of purple where it cannot be seen. Not exceptional but the best White for the money. 3 for $\$ 1.00$

\section{DWARF IRIS FOR ROCKERIES}

GRAMINEA, 5 inch. Red-violet 3 for $50 c$

ZWANENBURG (Dennis 1909) 15 inches. Olive bronze and buff.

3 for $50 c$

\section{SIBERIAN IRIS}

White $\$ 1.00 \mathrm{Doz}$

Blue $\$ 1.00 \mathrm{Doz}$

We feature also in our nurseries a complete collection of Japanese Flowering Cherries, Asiatic and Native Flowering Crab Apples, French Hybrid Philadelphus, French Hybrid Lilacs in more than one hundred varieties, Red and White Flowering Dogwood, a comprehensive collection of Azaleas and all of the better known flowering shrubs adapted to this climate. 

